\title{
Sequential Profiling of Anti-SARS CoV-2 IgG Antibody in Post COVID-19 Patients
}

\author{
Ajaikumar Sukumaran ${ }^{1}$ - Rhema Elizabeth Thomas $^{1} \cdot$ R. Arun Krishnan ${ }^{1} \cdot$ \\ Thushara Thomas ${ }^{1} \cdot$ Riji Thomas $^{1} \cdot$ Deepa K. Vijayan $^{1} \cdot$ Jofy. K. Paul $^{1}$ • \\ D. M. Vasudevan ${ }^{1}$
}

Received: 10 June 2021 / Accepted: 5 August 2021/Published online: 18 August 2021

(C) Association of Clinical Biochemists of India 2021

\begin{abstract}
Upon SARS CoV-2 infection, humoral immune system triggers production of anti-SARS CoV-2 IgM and IgG antibodies. Currently, antibodies against SARS CoV-2 spike protein receptor binding domain play a central role in disease protection, making them potential target for in vitro diagnostics applications. This study determines the expression level and sustainability of anti-receptor binding domain (RBD) SARS CoV-2 IgG in post COVID-19 patients. Anti-RBD SARS CoV-2 IgG antibodies in patient serum were analysed by standardised indirect ELISA using SARS CoV-2 spike receptor binding domain protein and HRP conjugated anti-human IgG antibody (anti-h IgG). The study was conducted using 35 adult patient samples with confirmed SARS CoV-2 infection. Additionally, correlation between antibody response after each stage and disease symptoms in post COVID-19 patients were studied. Maximum antibody titre was seen at Day 40 and decreased relatively to Day 180 in antibody positive samples when compared with controls. Overall, more IgG antibody expression is observed in patients who suffered from loss of smell and taste at Day $40.71 \%$ of the positive subjects in this study showed high SARS CoV-2 IgG antibody concentration of above $10 \mathrm{ng} / \mathrm{mL}$ and $37 \%$ showed strong antibody concentration above $20 \mathrm{ng} / \mathrm{mL}$ at the peak of seroconversion.
\end{abstract}

Keywords Anti-RBD SARS CoV-2 IgG · ELISA · HRP . Receptor binding domain · COVID-19

Ajaikumar Sukumaran

ajaiks28@gmail.com; ajaikumar.s@agappe.in

1 R\&D Reagent Department, Agappe Diagnostics Limited, Agappe Hills, Pattimattom P O, Cochin, Kerala 683562, India

\section{Introduction}

The interaction of spike glycoprotein to ACE 2 receptor facilitates the entry of SARS-CoV-2 virus into the host cells. Upon infection, the humoral immune system triggers the production of neutralizing and non-neutralizing antibodies against the viral antigenic regions to prevent further host cell infection [1, 2]. The seroconversion for antiSARS-CoV-2 IgM and IgG antibodies in case of COVID19 infection, commence after seven and fourteen days respectively. The level of antibody expression is highly variable among individuals and is depending on various factors like age, severity of symptoms, geographic area, nutritional status and medications. The extent of presence of antibodies in serum is also different from person to person and the protection offered by antibody titre against the secondary infection is still uncertain. In the current scenario, antibody quantification is having diminutive contribution in COVID-19 disease diagnosis; however, it is useful in identifying convalescent plasma donor, understanding population spread of the disease, checking the efficacy of vaccination and to identify prior exposure to SARS-CoV-2 infection [3-5].

In order to provide the antibody-mediated protection against the SARS-CoV-2 virus, the humoral immune response produces antibodies against the receptor binding domain (RBD) of spike protein and nucleocapsid proteins. It is reported that the $\mathrm{IgG}$ antibodies against the spike RBD provide more antibody-mediated protection than the antinucleocapsid antibodies. The uniqueness of RBD region among the coronavirus families, makes the anti-RBD IgG specific to each species. Hence the antibodies against RBD possess more neutralizing effect on the virus and are considered to be the most suitable antibody for the assessment of immunity against COVID-19 [6-11]. 
This study was focussed on quantifying the expression level and sustainability of anti-RBD SARS CoV-2 IgG in post COVID-19 patients for a period of 6 months. An indirect ELISA protocol has been standardized for the detection of anti-SARS CoV-2 IgG antibody qualitatively as well as quantitatively.

\section{Materials and Methods}

\section{Sample Collection}

Whole blood samples were collected intravenously from 35 COVID-19 infected patients (RT-PCR confirmed positive) and 135 healthy donors with no history of COVID-19 infection. The RT-PCR confirmed date for COVID-19 infection for each patient was considered as day zero in this study to evaluate the expression level of anti-SARS CoV-2 IgG antibody. The study was conducted with donors between age group 22-63 years. This study was performed with a written consent given by all patients for their samples to be stored and used for research purposes. A total of 144 serum samples were collected periodically from infected patients on days $40,80,120,150,180$ and were stored at $-20{ }^{\circ} \mathrm{C}$.

\section{Assay Components and Materials}

Transparent polystyrene high binding capacity microtiter plates (MC01F-H138) procured from Biomat Italy, Sephadex G-25M PD-10 columns, GE Healthcare UK, Amicon Ultra-4 centrifugal filter, Merck Millipore, Ireland. Bovine serum albumin fraction V from MP Biomedicals France, Horse radish peroxidase type II, D (+) Trehalose dihydrate, Gelatin, Tween-20, Ethanolamine, Sodium (meta) periodate, Sodium cyanoborohydride were purchased from Sigma-Aldrich, USA. Tetra methyl benzidine (TMB) from Thermofischer Scientific, USA, SARS-CoV-2 spike antigen from Fapon Biotech Inc. China and Antihuman IgG antibody from SenBT Corporation limited, China.

\section{Protocol Standardization for Anti SARS CoV-2 IgG antibody detection}

\section{Antigen Coating}

The SARS CoV-2 Spike Receptor Binding Domain protein, comprising 251-660 amino acid sequence, was used as the capture antigen in the assay development. The microtiter plates were coated with antigen at a concentration of $100 \mathrm{ng} / 100 \mu \mathrm{L} /$ well in $100 \mathrm{mM}$ Bicarbonate buffer,
$\mathrm{pH}$ 9.6. After the overnight incubation at $4{ }^{\circ} \mathrm{C}$, the plates were blocked with $0.5 \%$ gelatin in $10 \mathrm{mM}$ PBS buffer, $\mathrm{pH}$ 7.2 and kept for $1 \mathrm{~h}$ incubation at $37^{\circ} \mathrm{C}$. Further the plates were stabilized with $2 \% \mathrm{D}(+)$ trehalose dihydrate in $10 \mathrm{mM}$ PBS buffer, $\mathrm{pH} 7.2$ for $2 \mathrm{~h}$ at room temperature. Decant the plates, dried at room temperature for $30 \mathrm{~min}$, sealed in aluminium pouch and kept at $4{ }^{\circ} \mathrm{C}$ for storage. In order to maintain the homogeneity of antigen binding to the polystyrene the same lot (H101320) microtiter plates (MC01F-H138) were used for the entire study. To ensure the stability of the 96 well coated plates, 8 wells in each plates were dedicated for a 6-point calibration, one positive control and one negative control.

\section{Standards, Calibrator and Sample Preparation}

In order to analyse the antibody concentration in serum, the samples were subjected to 1:100 dilution in $10 \mathrm{mM}$ PBST buffer, $\mathrm{pH}$ 7.2. For quantitative analysis, the assay was calibrated with a standard linear graph with standard concentrations ranging from 15 to $0.45 \mathrm{ng} / \mathrm{mL}$. For qualitative assay calibrator with $2.5 \mathrm{ng} / \mathrm{mL}$ was used to make distinction between positive and negative samples based on the antibody ratio factor. The antibody ratio factor was calculated by dividing absorbance O.D of the sample by absorbance O.D of the calibrator. The calibrator O.D was standardized in such a way that the absorbance ratio factor 1.0 gives the distinction between positive and negative samples. The absorbance ratio factor of 1.0 corresponds to the calibrator concentration of $2.5 \mathrm{ng} / \mathrm{mL}$, which was assigned based on the maximum absorbance reading obtained from the negative samples.

\section{Detection Antibody Conjugation}

Anti-human IgG antibody (Anti-h IgG) conjugated to horse radish peroxidase enzyme (HRP) in 1:5000 dilution (in $10 \mathrm{mM}$ PBST buffer, $\mathrm{pH}$ 7.2) was used as the detection antibody in the assay. Sodium meta periodate $\left(\mathrm{NaIO}_{4}\right)$ oxidation-sodium cyanoborohydride reduction method has been optimized for facilitating the conjugation of Anti-h IgG to HRP. Initially $1 \mathrm{mg}$ of HRP was oxidized with $50 \mathrm{mM} \mathrm{NaIO}$ and subjected to PD-10 desalting column filtration against $100 \mathrm{mM}$ bicarbonate buffer. The anti-h $\mathrm{IgG}, 1 \mathrm{mg}$ was dialysed overnight against $100 \mathrm{mM}$ Bicarbonate buffer. Further both the oxidized HRP and the purified Anti-h IgG were concentrated using Amicon ultra4 centrifugal filter. The concentrated antibody and enzyme were mixed in equal volume and kept for $2 \mathrm{~h}$ with gentle mixing. The conjugated IgG-HRP complex was reduced by $2 \mathrm{M}$ sodium cyanoborohydride and unreacted aldehyde sites were blocked by the addition of $1 \mathrm{M}$ ethanolamine, pH 9.6. Finally, the conjugated IgG-HRP was subjected to 
Fig. 1 Qualitative ELISA-antiRBD SARS CoV-2 IgG

expression level
A

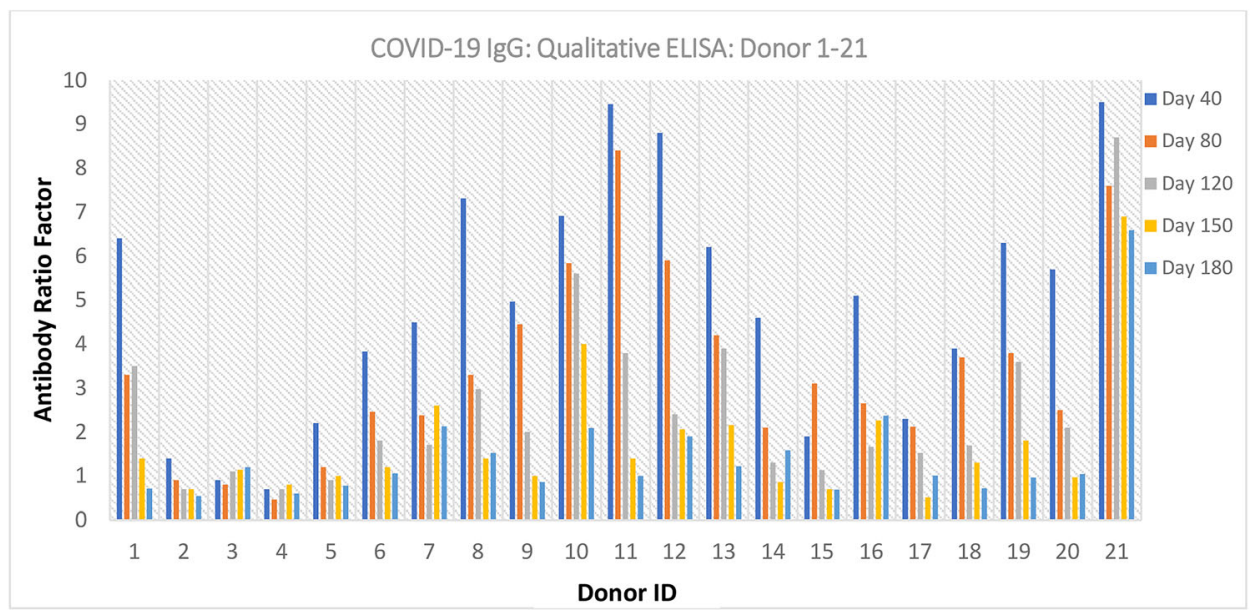

B

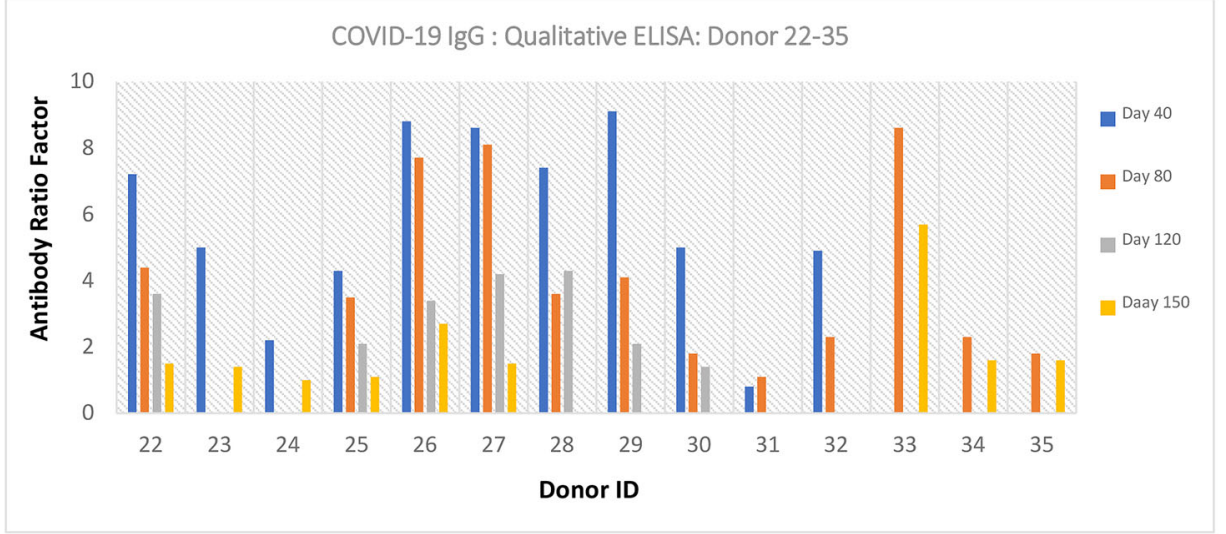

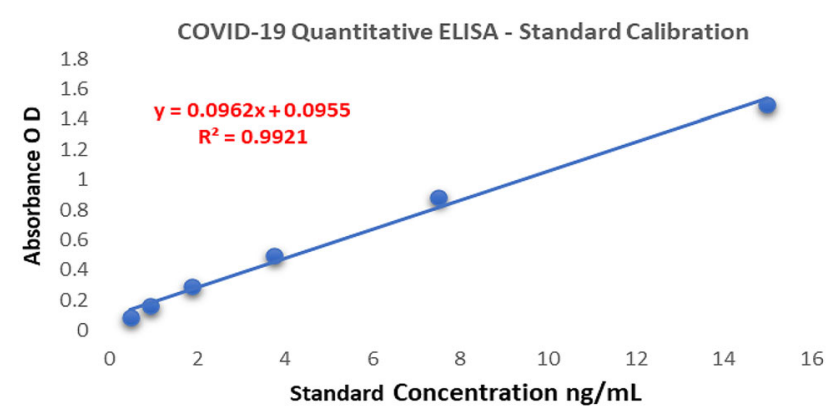

Fig. 2 Quantitative ELISA-anti-RBD SARS CoV-2 IgG-multipoint calibration

overnight dialysis against $50 \mathrm{mM}$ Tris buffer, $\mathrm{pH}$ 8.0. The working titre for conjugated antibody was decided by indirect ELISA, having coated spike RBD antigen and positive control as the primary antibody.

\section{Assay Protocol}

$100 \mu \mathrm{L}$ of standards, calibrator, samples (1:100 dilution) and blank were added to spike RBD antigen coated microtiter wells and kept for incubation at $37^{\circ} \mathrm{C}$ for $1 \mathrm{~h}$. The unbound antibodies were washed out with $10 \mathrm{mM}$ PBST buffer using Rayto-3100 ELISA washer.1:5000 diluted Anti-h IgG-HRP $100 \mu \mathrm{L} /$ well was added as the detector antibody and incubated for $1 \mathrm{~h}$ at $37{ }^{\circ} \mathrm{C}$. Again, washed the plates with $10 \mathrm{mM}$ PBST buffer in order to remove the unbound detector molecules. TMB/ $\mathrm{H}_{2} \mathrm{O}_{2}$ substrate, $100 \mu \mathrm{L} /$ well was added and incubated for $15 \mathrm{~min}$ at room temperature. $2 \mathrm{~N} \mathrm{H}_{2} \mathrm{SO}_{4}$ was used as the stopping reagent $(50 \mu \mathrm{L} /$ well $)$ and absorbance was measured at $450 \mathrm{~nm}$ in Rayto-2100 microplate reader. 
A

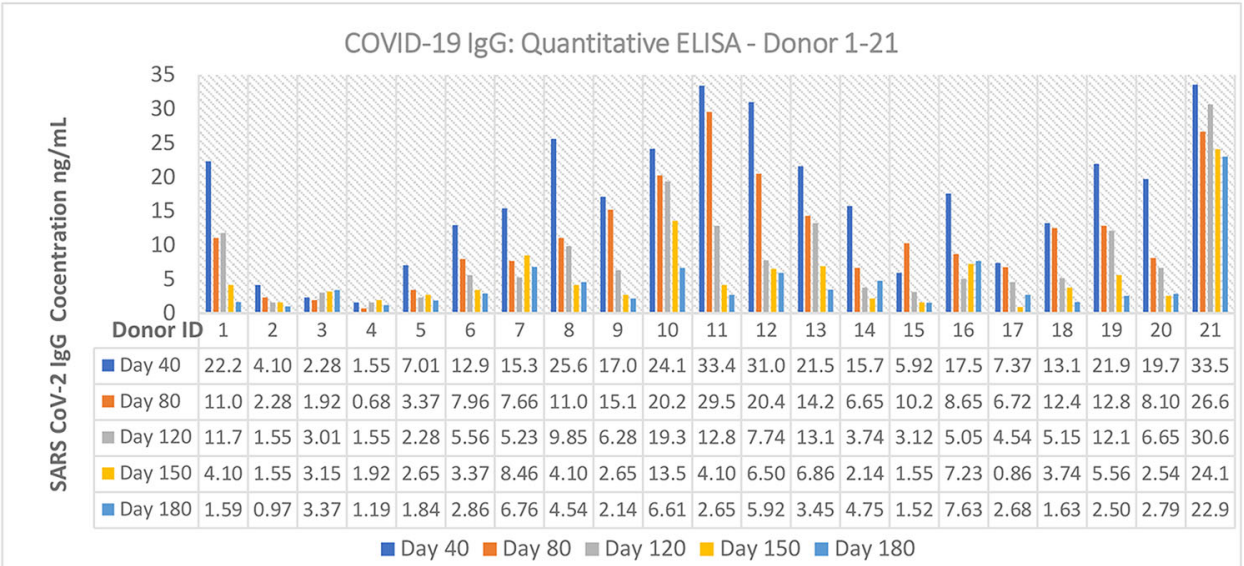

B

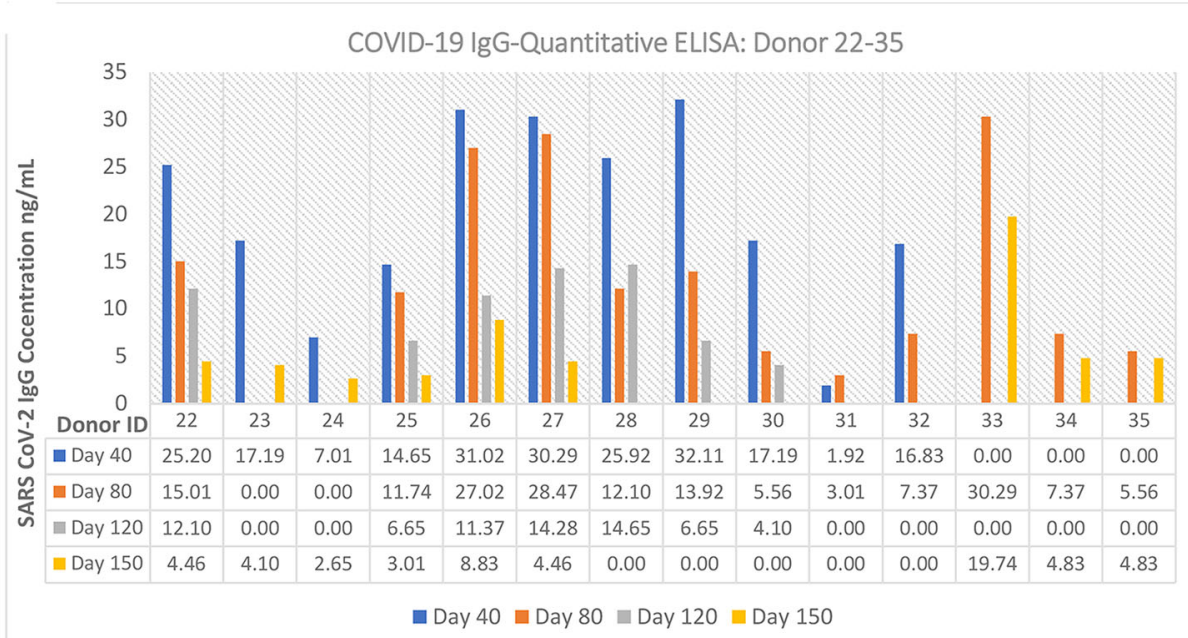

Fig. 3 Quantitative ELISA: anti-RBD SARS CoV-2 IgG expression level [0.00 values are SNC (sample not collected)]

\section{Results}

Out of 35 positive participants, 5 times sample collection and analysis (i.e., 40-180 days) were completed for 21 participants; Other 14 participants samples were collected and analysed for 2-4 times (i.e., 40-150 days), based on the COVID-19 infected dates. The results were analysed both qualitatively (based on single calibrator) and quantitatively (based on multipoint standard graph). It is evident from the results that the maximum antibody titre and concentration reached at around 40 days. Overall, in most patients by 180th day of post COVID-19 infection, showed very little antibody titre level. The antibody ratio factor and concentration values for each sample are the mean value of three independent tests. The developed assay could maintain the co-efficient of variation (CV) for the triplicate tests for the samples, calibrators and controls, below $5 \%$.

\section{Qualitative Analysis}

The one-point calibrator concentration used for qualitative analysis was $2.5 \mathrm{ng} / \mathrm{mL}$ and obtained an absorbance O.D of 0.35 with a CV of $4.41 \%$. Intra-run precision study with 20 tests had been done to assess the CV\% of the one-point calibrator $(2.5 \mathrm{ng} / \mathrm{mL}$ : 0.35 O.D). The maximum absorbance value obtained for negative samples $(n=135)$ in the standardized assay was 0.30 . In the case of positive samples based on the symptoms, severity and many other 
Table 1 Symptoms versus anti-RBD SARS CoV-2 IgG expression

\begin{tabular}{|c|c|c|c|c|c|c|c|c|c|c|c|c|c|}
\hline \multicolumn{2}{|c|}{ Donor } & \multicolumn{12}{|c|}{ Symptoms-during COVID-19 infection (information collected from the subjects orally) } \\
\hline ID & $\begin{array}{l}\text { Age } \\
\text { (years) }\end{array}$ & $\begin{array}{l}\text { Day } 40 \text { - Anti } \\
\text { SARS CoV-2 IgG } \\
\text { concentration } \\
(\mathrm{ng} / \mathrm{mL})\end{array}$ & Fever & Headache & Cough & Cold & Vomiting & Diarrhoea & $\begin{array}{l}\text { Loss } \\
\text { of } \\
\text { smell }\end{array}$ & $\begin{array}{l}\text { Loss } \\
\text { of } \\
\text { taste }\end{array}$ & $\begin{array}{l}\text { Body } \\
\text { pain }\end{array}$ & Fatigue & Dyspnea \\
\hline 1 & 28 & 22.29 & $\sqrt{ }$ & $\mathrm{X}$ & $\mathrm{X}$ & $\mathrm{X}$ & $\mathrm{X}$ & $\mathrm{X}$ & $\sqrt{ }$ & $\sqrt{ }$ & $\mathrm{X}$ & $\mathrm{X}$ & $X$ \\
\hline 2 & 28 & 4.10 & $\mathrm{x}$ & $\sqrt{ }$ & $\sqrt{ }$ & $X$ & $X$ & $X$ & $X$ & $X$ & $X$ & $X$ & $X$ \\
\hline 3 & 28 & 2.28 & $\sqrt{ }$ & $X$ & $\sqrt{ }$ & $X$ & $X$ & $X$ & $X$ & $X$ & $X$ & $X$ & $X$ \\
\hline 4 & 26 & 1.55 & $\sqrt{ }$ & $X$ & $X$ & $X$ & $X$ & $X$ & $X$ & $X$ & $X$ & $X$ & $X$ \\
\hline 5 & 35 & 7.01 & $\sqrt{ }$ & $\sqrt{ }$ & $X$ & $X$ & $X$ & $X$ & $X$ & $X$ & $\sqrt{ }$ & $X$ & $X$ \\
\hline 6 & 27 & 12.94 & $\sqrt{ }$ & $\sqrt{ }$ & $\sqrt{ }$ & $X$ & $X$ & $X$ & $\sqrt{ }$ & $\sqrt{ }$ & $\sqrt{ }$ & $X$ & $X$ \\
\hline 7 & 23 & 15.38 & $\sqrt{ }$ & $X$ & $\sqrt{ }$ & $X$ & $\sqrt{ }$ & $\sqrt{ }$ & $X$ & $X$ & $X$ & $\sqrt{ }$ & $X$ \\
\hline 8 & 22 & 25.60 & $\sqrt{ }$ & $X$ & $X$ & $X$ & $X$ & $X$ & $X$ & $X$ & $X$ & $X$ & $\sqrt{ }$ \\
\hline 9 & 26 & 17.09 & $\mathrm{x}$ & $\sqrt{ }$ & $\sqrt{ }$ & $X$ & $X$ & $X$ & $X$ & $X$ & $X$ & $X$ & $X$ \\
\hline 10 & 26 & 24.14 & $\mathrm{x}$ & $X$ & $X$ & $X$ & $X$ & $X$ & $X$ & $X$ & $X$ & $X$ & $X$ \\
\hline 11 & 29 & 33.42 & $\sqrt{ }$ & $\sqrt{ }$ & $X$ & $X$ & $X$ & $X$ & $X$ & $X$ & $X$ & $\sqrt{ }$ & $X$ \\
\hline 12 & 23 & 31.02 & $\sqrt{ }$ & $X$ & $X$ & $X$ & $X$ & $X$ & $\sqrt{ }$ & $\sqrt{ }$ & $X$ & $X$ & $X$ \\
\hline 13 & 30 & 21.56 & $\sqrt{ }$ & $\sqrt{ }$ & $\sqrt{ }$ & $X$ & $X$ & $X$ & $\sqrt{ }$ & $\sqrt{ }$ & $X$ & $X$ & $X$ \\
\hline 14 & 28 & 15.74 & $\mathrm{x}$ & $X$ & $X$ & $X$ & $X$ & $X$ & $X$ & $X$ & $X$ & $X$ & $X$ \\
\hline 15 & 28 & 5.92 & $\mathrm{x}$ & $\sqrt{ }$ & $X$ & $X$ & $X$ & $X$ & $X$ & $X$ & $\sqrt{ }$ & $\sqrt{ }$ & $X$ \\
\hline 16 & 29 & 17.56 & $\sqrt{ }$ & $\sqrt{ }$ & $\sqrt{ }$ & $X$ & $X$ & $X$ & $X$ & $X$ & $X$ & $X$ & $X$ \\
\hline 17 & 27 & 7.37 & $\mathrm{x}$ & $X$ & $\sqrt{ }$ & $X$ & $X$ & $X$ & $X$ & $X$ & $\sqrt{ }$ & $X$ & $X$ \\
\hline 18 & 26 & 13.19 & $\sqrt{ }$ & $\sqrt{ }$ & $X$ & $X$ & $X$ & $X$ & $X$ & $X$ & $\sqrt{ }$ & $X$ & $X$ \\
\hline 19 & 31 & 21.92 & $\sqrt{ }$ & $\sqrt{ }$ & $X$ & $X$ & $X$ & $X$ & $\sqrt{ }$ & $\sqrt{ }$ & $X$ & $X$ & $X$ \\
\hline 20 & 26 & 19.70 & $\sqrt{ }$ & $\sqrt{ }$ & $\sqrt{ }$ & $X$ & $X$ & $X$ & $X$ & $X$ & $X$ & $X$ & $X$ \\
\hline 21 & 50 & 33.56 & $\sqrt{ }$ & $\sqrt{ }$ & $\sqrt{ }$ & $X$ & $X$ & $X$ & $X$ & $X$ & $\sqrt{ }$ & $\sqrt{ }$ & $X$ \\
\hline 22 & 24 & 25.20 & $\sqrt{ }$ & $X$ & $X$ & $X$ & $X$ & $X$ & $\sqrt{ }$ & $X$ & $X$ & $X$ & $X$ \\
\hline 23 & 56 & 17.19 & $\sqrt{ }$ & $X$ & $X$ & $X$ & $X$ & $X$ & $X$ & $X$ & $X$ & $X$ & $X$ \\
\hline 24 & 63 & 7.01 & $\mathrm{x}$ & $X$ & $\sqrt{ }$ & $X$ & $X$ & $X$ & $X$ & $X$ & $\sqrt{ }$ & $X$ & $X$ \\
\hline 25 & 33 & 14.65 & $\mathrm{x}$ & $X$ & $X$ & $X$ & $X$ & $X$ & $\sqrt{ }$ & $X$ & $X$ & $X$ & $X$ \\
\hline 26 & 38 & 31.02 & $\sqrt{ }$ & $X$ & $\sqrt{ }$ & $\sqrt{ }$ & $X$ & $X$ & $X$ & $X$ & $X$ & $\sqrt{ }$ & $X$ \\
\hline 27 & 34 & 30.29 & $\mathrm{x}$ & $X$ & $X$ & $X$ & $X$ & $X$ & $\sqrt{ }$ & $\sqrt{ }$ & $\sqrt{ }$ & $X$ & $X$ \\
\hline 28 & 33 & 25.92 & $\mathrm{x}$ & $\sqrt{ }$ & $\sqrt{ }$ & $X$ & $X$ & $X$ & $X$ & $X$ & $\sqrt{ }$ & $X$ & $X$ \\
\hline 29 & 32 & 32.11 & $\mathrm{x}$ & $X$ & $X$ & $\sqrt{ }$ & $X$ & $X$ & $X$ & $X$ & $\sqrt{ }$ & $X$ & $X$ \\
\hline 30 & 54 & 17.19 & $\sqrt{ }$ & $X$ & $X$ & $X$ & $X$ & $X$ & $X$ & $X$ & $\sqrt{ }$ & $\sqrt{ }$ & $X$ \\
\hline 31 & 30 & 1.92 & $\mathrm{x}$ & $X$ & $X$ & $X$ & $X$ & $X$ & $X$ & $X$ & $\sqrt{ }$ & $\sqrt{ }$ & $X$ \\
\hline 32 & 58 & 16.83 & $\sqrt{ }$ & $\sqrt{ }$ & $\sqrt{ }$ & $X$ & $\sqrt{ }$ & $\sqrt{ }$ & $\sqrt{ }$ & $\sqrt{ }$ & $X$ & $\sqrt{ }$ & $X$ \\
\hline 33 & 36 & SNC & $\sqrt{ }$ & $\sqrt{ }$ & $X$ & $X$ & $X$ & $\mathrm{x}$ & $X$ & $X$ & $\sqrt{ }$ & $\sqrt{ }$ & $X$ \\
\hline 34 & 38 & SNC & $\sqrt{ }$ & $\sqrt{ }$ & $\sqrt{ }$ & $X$ & $X$ & $\mathrm{x}$ & $X$ & $X$ & $\sqrt{ }$ & $X$ & $X$ \\
\hline 35 & 49 & SNC & $\mathrm{x}$ & $X$ & X & $X$ & $X$ & $\mathrm{x}$ & $X$ & $X$ & $X$ & $X$ & $X$ \\
\hline
\end{tabular}

${ }^{*}$ SNC sample not collected

factors, the antibody titres drastically varied from person to person. The antibody ratio factor varies from 1.0 to 9.5 among the positive samples in this study (Fig. 1).

\section{Quantitative Analysis}

The anti-RBD SARS CoV-2 IgG antibody in serum has been quantified using multipoint standard calibration ranging from 15 to $0.4 \mathrm{ng} / \mathrm{mL}$. (Fig. 2). A linear graph was obtained having $15 \mathrm{ng} / \mathrm{mL}$ linearity with a regression 


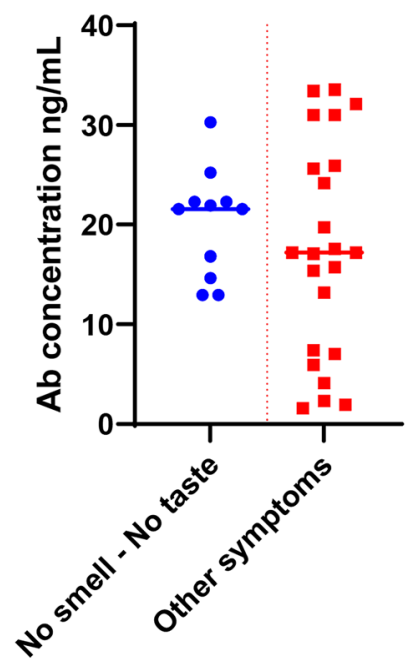

Fig. 4 Correlating symptoms to anti-RBD SARS CoV-2 IgG antibody expression

coefficient of $99.21 \%$. The limit of linearity of the developed assay is $50 \mathrm{ng} / \mathrm{mL}$.

Similar to the qualitative analysis report, the antibody concentration in serum samples showed gradual decreasing trend from day 40-180. Based on both qualitative and quantitative analysis, a concentration value below $2.5 \mathrm{ng} /$ $\mathrm{mL}$ (absorbance OD $<0.30$ ) was considered as the negative sample/negligible antibody titre for anti-RBD SARS $\mathrm{CoV}-2 \mathrm{IgG}$ and value $>2.5 \mathrm{ng} / \mathrm{mL}$ was considered as positive samples (Fig. 3). All the negative samples used in this study showed concentration below $2.5 \mathrm{ng} / \mathrm{mL}$ for the quantitative assay.

From the result it is evident that, in most cases, after the COVID-19 infection, seroconverted IgG antibodies will be persistent in blood at a detectable level for a minimum of 150-180 days. Only one positive donor (samples from 40 to 180 days) showed negative results for anti-RBD SARSCoV-2 antibody throughout the study period and the reason for that is unclear.

\section{COVID-19 Symptoms versus Seroconversion}

A correlation between the COVID-19 symptoms and the expression of anti-RBD SARS CoV-2 IgG was analysed with the information collected from the donors and the experimental results (Table 1).

It is observed that the age does not show considerable significance in seroconversion rate and pace. The expression level and persistence of anti-RBD SARS CoV-2 IgG antibody were greater in patients with symptoms like high fever, loss of smell, loss of taste and cough. The aforementioned data table provides an interesting link between the peculiar symptoms of COVID-19 like loss of smell and taste with the seroconversion of IgG. All the patients who faced loss of smell and taste symptoms (information obtained from the subjects orally), the anti-RBD SARS CoV-2 IgG antibody concentration was above $10 \mathrm{ng} / \mathrm{mL}$ or more by day 40 (Fig. 4).

$71 \%$ of the positive patients in this study showed high anti-RBD SARS CoV-2 IgG antibody concentration of above $10 \mathrm{ng} / \mathrm{mL}$ at the peak of seroconversion. Out of these $71 \%, 86 \%$ were having anti-RBD SARS CoV-2 IgG concentration above $5 \mathrm{ng} / \mathrm{mL}$ even after 120 days of infection. At the same time $37 \%$ showed strong antibody concentration above $20 \mathrm{ng} / \mathrm{mL}$ at the peak of seroconversion; $85 \%$ of this showed persistence of antibody above $10 \mathrm{ng} / \mathrm{mL}$ for 120 days. 3 out of 35 positive donors claimed no symptoms during the COVID-19 infection but showed an average antibody titre for anti-RBD SARS CoV-2 IgG during the study period.

\section{Conclusion}

With the standardized indirect ELISA protocol, the study could reveal the expression level and persistence of antiRBD SARS CoV-2 IgG antibody in human serum. Further studies are needed to confirm the ability of sustainable antiRBD SARS CoV-2 IgG in blood, against a secondary infection by SARS CoV-2 virus. The donors in this study neither were faced secondary infection nor vaccinated for COVID-19. Hence, based on this study a minimum of 6-month protection from secondary COVID-19 infection can be expected. Even though, the available data provided an interesting correlation among the symptoms and antibody expression level, more samples comparison is inevitable to strengthen the findings.

\section{Declarations}

Conflict of interest All authors declare that they have no conflict of interest.

Informed consent Written permission taken from each donor for collecting and using the serum samples for research purpose.

\section{References}

1. Ogata A, Maley A, Wu C, Gilboa T, Norman M, et al. Ultrasensitive serial profiling of SARS-CoV-2 antigens and antibodies in plasma to understand disease progression in COVID-19 patients with severe disease. Clin Chem. 2020;66(12):1562-72.

2. Tang M, Case J, Franks C, Chen R, et al. Association between SARS-CoV-2 neutralizing antibodies and commercial serological assays. Clin Chem. 2020;66(12):1538-47.

3. Qu J, Wu C, Li X, Zhang G, et al. Profile of immunoglobulin G and $\operatorname{IgM}$ antibodies against severe acute respiratory syndrome coronavirus 2 (SARS-CoV-2). Clin Infect Dis. 2020;71(16):2255-8. 
4. Wang, Y., Li, J., Li, H., Lei, P., et al. Persistence of SARS-CoV2-specific antibodies in COVID-19 patients. Int Immunopharmacol. 2021;90:107271.

5. Liu A, Li Y, Peng J, Huang Y, Xu D. Antibody responses against SARS-CoV-2 in COVID-19 patients. J Med Virol. 2020;93(1):144-8.

6. Suhandynata RT, Hoffman MA, Kelner MJ, McLawhon RW, Reed SL, Fitzgerald RL. Multi-platform comparison of SARSCoV-2 serology assays for the detection of COVID-19. J Appl Lab Med. 2020;5(6):1324-36.

7. Mehdi, F., Chattopadhyay, S., Thiruvengadam, R., Yadav, S., et al. Development of a Fast SARS-CoV-2 IgG ELISA, based on receptor-binding domain, and its comparative evaluation using temporally segregated samples from RT-PCR positive individuals. Front. Microbiol. 2021;11.

8. Yadav P, Sapkal G, Shete-Aich A, Jain R, et al. Development of indigenous IgG ELISA for the detection of anti-SARS-CoV-2 IgG. Indian J Med Res. 2020;151(5):444.
9. Muench, P., Jochum, S., Wenderoth, V., Ofenloch-Haehnle, B., et al. Development and validation of the elecsys anti-SARS-CoV2 immunoassay as a highly specific tool for determining past exposure to SARS-CoV-2. J Clin Microbiol. 2020;58(10).

10. Sil B, Jahan N, Haq M, Oishee M, et al. Development and performance evaluation of a rapid in-house ELISA for retrospective serosurveillance of SARS-CoV-2. PLoS One. 2021;16(2):0246346.

11. Alandijany T, El-Kafrawy S, Tolah A, Sohrab S, et al. Development and optimization of in-house ELISA for detection of human IgG antibody to SARS-CoV-2 full length spike protein. Pathogens. 2020;9(10):80.

Publisher's Note Springer Nature remains neutral with regard to jurisdictional claims in published maps and institutional affiliations. 